\title{
Microstructural Analysis of Nickel Influence in Alsi10mgmn Alloy with Increased Iron Level
}

Maria Zihalova ${ }^{1}$, Dana Bolibruchova ${ }^{1}$, Jaromir Cais ${ }^{2}$

${ }^{1}$ Department of Technological Engineering, Faculty of Mechanical Engineering, University of Zilina, Univerzitna 8215/1, 01026 Zilina. Slovak Republic. E-mail: maria.zihalova@fstroj.uniza.sk, danka.bolibruchova@ fstroj.uniza.sk

${ }^{2}$ Faculty of Production Technology and Management, J. E. Purkyne University in Usti nad Labem. Pasteurova 3334/7, 40001 Usti nad Labem. Czech Republic. E-mail: cais@fvtm.ujep.cz

Presence of iron in Al-Si-Mg based alloys is a common problem. Due to low solubility of iron in aluminium, most of the iron is present in the form of intermetallic phases, which decrease mechanical and foundry properties of the alloy. Addition of some chemical elements might be used to elimination of iron effects. In the article, influence of nickel to microstructure of AISi10MgMn alloy with $1 \mathrm{wt}$. \% of iron is described. Addition of nickel to elimination of iron influence is $0.1,0.3$ and $0.5 \mathrm{wt}$. \%, respectively. Shape and chemical composition of the intermetallic phases is the main concern of the research as the main factor responsible for decrease of the properties of aluminium alloys with high amount of iron. It has been shown that nickel has a positive influence to iron-based intermetallics in higher levels.

Keywords: AlSi10MgMn alloy, Microstructural analysis, Iron intermetallics, Nickel addition, EDX analysis

\section{Acknowledgement}

This work was created in the framework of the grant project VEGA $N^{\circ} 1 / 0363 / 13$. The authors acknowledge the grant agency for support.

\section{References}

[1] BOLIBRUCHOVA, D., TILLOVA, E. (2005). Zlievarenske zliatiny Al-Si, pp. 180, ZU Zilina, Zilina.

[2] PASTIRCAK, R. (2014). Effect of Low Pressure Application during Solidification on Microstructure of Al-Si Alloys. In: Manufacturing Technology, Vol. 14, No. 3, pp. 397-400. J.E. Purkyne University in Usti nad Labem, Usti nad Labem, CR.

[3] TILlOVA, E., CHALUPOVA, M. (2009). Strukturna analyza zliatin Al-Si, pp. 191, EDIS, Zilina.

[4] HURTAlOVA, L., TILLOVA, E. (2013). Elimination of the negative effect of Fe-rich intermetallic phases in secondary (recycled) aluminium cast alloy. In: Manufacturing Technology, Vol. 13, No. 1, pp. 44-50. J.E. Purkyne University in Usti nad Labem, Usti nad Labem, CR.

[5] SHABESTARI, S.G. (2004). The effect of iron and manganese on the formation of intermetallic compounds in aluminium-silicon alloys. In: Materials Science and Engineering A, Vol. 383, pp. 289-298.

[6] HWANG, J.Y., DOTY, H.W., KAUFMAN, M.J. (2008). The effects of Mn additions on the microstructure and mechanical properties of Al-Si-Cu casting alloys. In: Materials Science and Engineering A, Vol. 488, pp. 496504.

[7] DINNIS, C.M., TAYLOR, J.A., DAHLE, A.K. (2005). As-cast morphology of iron-intermetallics in Al-Si foundry alloys. In: Scripta Materialia, Vol. 53, pp. 955-958.

[8] BRUNA, M., KUCHARCIK, L., SLADEK, A. (2013). Complex Evaluation of Porosity in A356 Aluminium Alloy using Advanced Porosity Module. In: Manufacturing Technology, Vol. 13, No.1, pp. 26-30. J.E. Purkyne University in Usti nad Labem, Usti nad Labem, CR.

[9] TAYLOR, J.A. (2012). Iron-containing intermetallic phases in Al-Si based casting alloys. In: Procedia Materials Science, Vol. 1, pp. 19-33.

[10] LIU, K., CAO, X., CHEN, X.-G. (2011). Solidification of Iron-Rich Intermetallic Phases in Al-4.5Cu-0.3Fe Cast Alloy. In: Metallurgical and Materials Transactions A, Vol. 42A, pp. 2004-2016.

[11] EIDHED, W. (2008). Modification of $\beta-\mathrm{Al}_{5} \mathrm{FeSi}$ Compound in Recycled Al-Si-Fe Cast Alloy by Using $\mathrm{Sr}, \mathrm{Mg}$ and Cr Additions. In: Journal of Materials Science and Technology, Vol. 24, No. 1, pp. 45-47.

[12] PETRIK, J., SZARVASY, P., SPETUCH, V. (2004). The properties of iron, nickel and manganese containing AlSi alloy. In: Acta Metallurgica Slovaca, Vol. 10, No. 2, pp. 73-79. (in Slovak) 
[13] PETRIK, J., HORVATH, M. (2011). The iron correctors in Al-Si alloys. In Annals of Faculty Engineering Hunedoara - International Journal of Engineering, Vol 9, No. 3, pp. 401-405. University Politehnica Timisoara, Romania.

[14] ASM. (1992). ASM Handbook. Volume 3. Alloy Phase Diagrams, pp. 1741. ASM International. USA.

[15] MICHNA, S. et al. (2005). Encyklopedie hliniku, pp. 722. Adin, Prešov.

[16] CHEN, C.-L., THOMSON, R.C. (2010). The combined EBSD and EDX analyses for the identification of complex intermetallic phases in multicomponent Al-Si piston alloys. In: Journal of Alloys and Compounds, Vol. 490, pp. 293-300.

\section{Paper number: M2015134}

Copyright (c) 2015. Published by Manufacturing Technology. All rights reserved. 